\title{
History of Science and Technology
}

\author{
Fourth INTERNATIONAL CONGRESS
}

\begin{abstract}
$\mathrm{T}$ HE fourth International Congress of the History of Science and Technology was held in Prague on September 22-27 under the presidency of Prof. Quido Vetter. A few days prior to the Congress, Czechoslovakia had been struck a cruel blow by the death of the President-Liberator of the Czechoslovakian Republic, Dr. T. G. Masaryk. The delegates to the Congress assembled on the day of the funeral, and as was to beo expected at such a time of national mourning, the Congress opened under a cloud of sadness. The social functions previously announced did not take place, but otherwise the whole programme of work was completed.

The conference, which was most successful, was attended by about two hundred and fifty members, including a distinguished group of Czechoslovakian scholars and scientific workers, as well as by delegates from twenty-four other countries. Official delegates had been sent by the Governments of the Argentine, Austria, Bulgaria, Great Britain, Italy, Latvia, Mexico, Rumania, Spain, Sweden, Switzerland and the United States, while the leading foreign academies of science, scientific societies and universities were also represented. The absence of representatives from Germany, however, was noticeable.
\end{abstract}

The meeting coincided with the one hundred and fiftieth anniversary of the birth of J. E. Purkynè, the famous Czechoslovak biologist, and delegates were invited to take part in the international celebration and conference which had been arranged by the Purkyne Society to commemorate the occasion. A visit was also made to the tomb of Purkyner at Vyšehrad. It had previously been recommended to the International Academy that the Congress should deal with the development of sciences in the eighteenth century and in the first half of the nineteenth century, while as a second subject the "History of Science in Instruction" was proposed.

The opening session of the Congress was held in the well-appointed Purkyner Hall of the Institute of Medicine, at the University of Charles IV, under the presidency of Prof. Q. Vetter, president of the Congress. The delegates were welcomed on behalf of the Czechoslovakian Government by Dr. E. Franke, Minister of Public Instruction. Prof. Charles Singer, who led the British delegation, communicated friendly greetings and good wishes from Great Britain for the success of the conference, and similar messages of good will were expressed by several other foreign delegates. The inaugural address was then given by Prof. Boh. Němec on the subject "From Newton to Darwin".

On the following day an address on "The Spirit of Science in History" was given by Prof. Singer before one of the plenary sessions of the Congress. He pointed out that the ultimate aim of the scientific mood-as of the other great moods, the religious and the artistic-is to integrate the outer with the inner world. $\mathrm{H}_{e}$ emphasized that the scientific mood must demand independence of all the other judgments that influence mankind, such as those based on fashion, tradition, taste, nationality or class, and showed that science is of all studies the most truly man-wide, humane and international.

Prof. G. Loria of Genoa gave an interesting account of a study of the geometric representation of values in the different epochs in the history of mathematics, and indicated the conclusions he had deduced from these researches. Dr. Joseph Mayer of Washington directed attention to the reasons why the social sciences lag behind the physical and biological sciences, which have moved forward with umprecedented rapidity during the last hundred to hundred and fifty years. He showed that, at any rate in the light of the history of science, we can at least understand why there is so much uncertainty, hesitation and apparent misunderstanding in contemporary efforts to solve social problems. Other addresses given before the plenary sessions included "The Biological Cosmologies of the Nineteenth Century" by Prof. Otto Grosser, "The Development of Agriculture in Czechoslovakia" by Dr. F. Lom, "The Beginning of Scientific Life among the Rumanians" by Prof. Valeriu Bologa, "Purkyner and the Cellular Theory" by Prof. F. K. Studnička.

The work of the Congress itself was divided into six main sections, namely, $(a)$ general science, $(b)$ mathematics, (c) natural science, $(d)$ medicine, $(e)$ agriculture, $(f)$ technical science. Approximately one hundred and fifty papers, which covered an extremely wide range of subjects, were scheduled for presentation and discussion at these meetings. A memorial meeting was held on the occasion of the one hundred and fiftieth anniversary of the birth of J. E. Purkyně, under the ægis of the Purkyner Society, in the Pantheon of the National Museum on Saturday, September 25, when representatives of universities and scientific societies commemorated the genius of that eminent man of science. The Minister of Education, Dr. Emil Franke, addressed the meeting on behalf of the Czechoslovak Government, and Prof. B. Nermec gave an appreciation of Purkyně's work.

The success of the Congress was assured by the cordial hospitality extended to the delegates by the people of Czechoslovakia, and by the well-organized arrangements made by the committee. The delegates were able to visit the many historical buildings and monuments with which Prague is so richly endowed, and were privileged also to inspect the library of the monastery of Prémonstrats at Strahov. Excursions were also made to Karlstein, Krrivoklát, Blatná and Strakonice.

A special exhibition of documents relating to the "History of Science in Czechoslovakia" was arranged in the Clementinum, and in the National Museum by the organizing committee with the co-operation of the National Museum, the National Library and the University, while a catalogue of the exhibits was specially prepared for distribution to the members of the Congress. An exhibition of documents and personal relics relating to J. E. Purkyner was also arranged by the Purkyně Society. Another exhibition, of modern scientific and technical literature in Czechoslovakia, was specially arranged, and attracted much attention. 
At the opening ceremony of the exhibition in the Clementinum, the delegates enjoyed a performance to ancient Bohemian polyphonous music sung by the Bohemian madrigalists conducted by Prof. B. Špidra. This improvised concert deeply impressed the visitors, as also did the compositions of Rejcha and Mozart played in the large hall of the Wallen. stein Palace by the Prague brass quintette. The performance of Weber's "Oberon" in the Prague German Theatre, and that of Smetana's "Libuše" in the National Theatre, as well as the concert of the Czech Philharmonic Orchestra at the Smetana Hall conducted by Mr. Rafael Kubelik, offered further opportunities for the delegates to become acquainted with the cultural life of Czechoslovakia.

Among the resolutions submitted and approved at the final meeting of the Congress was a proposal that history of science should be included in the teaching of secondary and high schools, and also a request for the publication of Isaac Newton's correspondence.

An invitation from the Swiss Government to hold the next congress at Lausanne in 1940 was accepted, and Prof. Arnold Raymond, formerly rector of the University of Lausanne, was elected president. An invitation from the Brazilian Government to an extraordinary congress in 1938 was also accepted.

\section{Overvoltage in Light and Heavy Water}

$\mathrm{B}^{\mathrm{x}}$ means of the polarographic method with a dropping mercury cathode, Prof. J. Heyrovský, in collaboration with Dr. J. Novák, has been able to advance knowledge of hydrogen overvoltage (Coll. Czechoslovak Chem. Com., 9, 207, 273 and 344; 1937). By this delicate method they were able to register significant differences in current voltage curves in light and heavy water, with special reference tc hydrogen overvoltage. They find that in $0.001 \mathrm{~N}$ hydrochloric acid in ordinary water at $20^{\circ} \mathrm{C}$. the overvoltage differs from that in $99 \cdot 6$ per cent deuterium oxide by +87 millivolts; in 94.6 per cent $\mathrm{D}_{2} \mathrm{O}$ by 63 millivolts; in 76.5 per cent $\mathrm{D}_{2} \mathrm{O}$ by $31 \mathrm{mv}$. and in 49.8 per cent $\mathrm{D}_{2} \mathrm{O}$ by $15 \mathrm{mv}$. At $60^{\circ} \mathrm{C}$. the differences with the purest heavy water is +71 millivolts. The factor $b$ in Tafel's term, $b \log i$, is 113 millivolts at $20^{\circ} \mathrm{C}$. in heavy water and 102 in light water.

The electro-reduction of hydrogen peroxide is similarly inhibited in heavy water. On the other hand, the electro-reduction of oxygen, and of maleic acid in acetic acid solution, and the electro-deposition of thallous ions in heavy water proceed at an unchanged potential or at a distinctly more positive one than in light water. The theoretical significance of these experimental results is discussed by Prof. Heyrovský, who gives a general theory of hydrogen overvoltage which appears to account well for the observed facts. $\mathrm{He}$ regards the electro-deposition of the isotopic hydrions as indifferent, but the evolution of hydrogen, including its molalization, as 5.4 times less in heavy water ; 5.4 is the ratio of the ionic products of $\mathrm{H}_{2} \mathrm{O}$ and $\mathrm{D}_{2} \mathrm{O}$, and signifies that the rate of dissociation of water is $5 \cdot 4$ times that of deuterium oxide. The molalization takes place through the interaction of the deposited hydrogen atoms with the hydrions of the solution:

$$
\mathrm{H}+\mathrm{H}^{+}=\mathrm{H}_{2}+
$$

The formula finally deduced for the overvoltage is

$$
\begin{array}{r}
\pi=+\frac{R T}{F} \log \frac{([\mathrm{H}+]+[\mathrm{D}+])^{2}}{i+\bar{\omega} i^{2}}\left(C_{\mathrm{H}_{2} \mathrm{O}} K_{1}+C_{\mathrm{HOD}}\right. \\
\left.\left(K_{1}^{\prime}+K_{2}{ }^{\prime}\right)+C_{\mathrm{D}_{2} \mathrm{O}} K_{2}\right),
\end{array}
$$

where $\tilde{\omega}$ is the mean adsorption coefficient of the freshly formed hydrogen molecules, $\mathrm{CH}_{2} \mathrm{O}, C \mathrm{HOD}$ and $\mathrm{CD}_{2} \mathrm{O}$ denote the molar fractions of the solvent, and $K_{1}\left(K_{1}^{\prime}+K_{2}^{\prime}\right)$ and $K_{2}$ are the dissociation constants of $\mathrm{H}_{2} \mathrm{O}$, HOD and $\mathrm{D}_{2} \mathrm{O}$ respectively.

The validity of the equation has been tested by substituting calculated quantities of light and heavy water, and the observed results are in good agreement with theoretical requirements. The electrolytic separation coefficient for the hydrogen isotopes at cathodes with large overvoltage is dependent on the composition of the mixture and on the current density. The mean value of $5 \cdot 4$ should increase to 50 in concentrated heavy water and decrease to $2 \cdot 7$ in ordinary water.

\section{Employment of University Graduates}

Y FidR by year some 15,000 students enter the universities of Great Britain. Their intentions, hopes and aspirations and those of their parents and other counsellors are almost as various as their pedigrees, but they are admitted on the assumption that their undergraduate years are to be dedicated more or less to preparation for their life's work, and the shaping of university policies is to a large extent determined by that ideal. In their careers after the completion of their undergraduate courses, the value of that preparation is tested, and the employment of graduates is, obviously, a matter of concern not only to them but also to university administrators and to the community as a whole.

The University Grants Committee in its quinquennial report published last year dealt at consider. able length with problems of student numbers and employment. This year the National Union of Students held a Congress at Southampton on April I-8, at which these formed the main subject of 